attention to the study of the funsi occurring in their districts. The subject was introduced by $\mathrm{Mr}$. Carleton Rea, of Worcester, at the instance of the British Mycological Society. It was pointed out by Mr. Rea that British botanists generally omit fungi from the county floras, or give lists that are compiled without the necessary local knowledge. Yet the group ill deserves neglect, for it is one of great economic importance. It is said that the cereal rusts cost Prussia in one year 20,900,00ol. To encourage the study of British fungi, the Woolhope Naturalists' Club in ' 1868 instituted a series of autumnal forays, and some other natural-history clubs, like the Essex Field Club, have followed the example; but this occasional study is insufficient. The fungi should be studied throughout the year, and specimens displayed for exhibition at all times in the society's rooms or in the local museum. In the course of the discussion, Prof. J. W. Carr, of Nottingham, and some other naturalists, dwelt on the difficulty of working out the fungi of a given district in consequence of the general lack of expert knowledge. Mr. Rea, however, considered it the duty of each society to be able to determine the fungi of its own area, without submitting them, except in difficult cases, to a mycological referee. A large collection of handcoloured photographs of fungi, taken by $\mathrm{Mr}$. A. Wallis, of Kettering, was exhibited by Mr. H. N. Dixon.

Several delegates from the sections explained in what way the local scientific societies might aid the sectional committees. Mr. Wilfrid Mark IVebb appealed for specimens of centipedes in illustration of a work on which he was engaged, but the Rev. Thomas Stebbing explained that his repeated request for well-shrimps had met with no response from any of the local societies through their delegates.

\section{HEALTH AND EDUCATION.}

THE Health Education League of Boston, Massachusetts, U.S.A., has issued a series of small pamphlets dealing with the common aspect of our daily life from a health point of view. Mrs 1 . Richards appears to be the moving sp/rit in thy tseful sanitary campaign, and directors of the lesie several medical men. The usefulness of the hives contained in these tiny publications is undoubted. all the more so because they are tiny, and because fe facts they set forth are stated in terms readily to be understood by everyone.

The first of the series gives "Hints for Health in Hot Weather." In it we find sensible remarks, under the heading of "Rules for Children," "Cleanliness," \&c., concerning the general bringing up of children, but, except the benefits of sunshine and the use of wire screens to keep out mosquitoes, we are told all too little about bodily protection in hot weather.

No. 2 of the series deals with milk. The story of milk as a food and as a vehicle of disease is admirably told. The meaning of unwholesome milk, how it is brought about, and how prevented by chilling and sterilising, is described and fully explained; the information contained in this pamphlet is an education to the public in the very best sense.

"Colds and their Prevention" is dealt with in series No. 3. Under this heading the subject of ventilation is skilfully introduced. The care of the skin and of the feet is also incorporated in the text.

No. 4 of the series is concerned with "Meat and Drink." Good nutrition is held to be of vital importance to our courage, cheerfulness, and physical efficiency, and the meaning of cooking and the effects of boiling, roasting, frying, \&c., scientifically yet simply explained.

"Healthful Homes" is the subject of No. 5. The moral atmosphere of family life is dwelt upon as an important factor in national life, and the practical details of elementary hygiene and sanitation are here collected and set forth in admirable fashion.

"The Successful Woman" (series No. 6) pamphlet tells the business woman how to keep well, and good and sensible rules and suggestions are laid down for her guidance. Most of us would hesitate to stamp a business No. I976, vกI. 76$]$ woman, that is, one whose chief ideal is to keep well, so " that she may earn a full salary," as one of nature's successful productions. That women should be compelled to, or by choice, take to business cannot but be regarded as one of the blots of our civilisation of which we ought to be heartily ashamed. To stamp a woman so engaged as a successful woman is rather encouraging woman along a side-path of doubtful benefit to the racc.

"The Boy and the Cigarette" (series No: 7) should be read by everyone, and the recommendations against this poisonous and harmful practice should be stringently enforced by law in the case of boys. Women are warned that neither their brothers nor their admirers think better of them for smoking cigarettes. A woman who smokes is spoken of in a ribald manner, did women but know it, by men in private, and their morality made a subject of question and banter.

"The Care of Little Children" (series No. 8) is replete with good advice, and can be heartily commended; and the fact that the future health and welfare of the individual is mostly determined by the wisdom or folly bestowed upon the infant during the first few weeks of life pointedly brought home.

"The Plague of Mosquitoes and Flies" constitutes the subject of series No. 9. It is a timely contribution, and contains the most recent lessons we have learned concerning the spread of disease. We know within recent years that our household pests and pets, the flies, fleas, bugs, and other vermin which inhabit our houses, and our dogs, cats, fowls, mice, rats, \&c., are frequent media of the transmission of diseases. It is a great advance in knowledge, one of the greatest hygienic advances since Parker first brought the subject systematically before the world. This pamphlet should be distributed broadcast, and the subject it deals with taught in every school.

No. II of the series points out, under the title of "Tonics and Stimulants," the necessity for temperance in the use of alcohol, tea and coffee, and drugs. The lessons in this short pamphlet are well taught, and the advice wise and wholesome.

The series as a whole is an unfortunate necessity. It implies that mankind, in modern days, has so lost touch with nature and nature's ways that the instinct of the care of the young, which belongs in common to all animals, is a lost attribute of modern men and women. Perhaps it is wise to recognise the fact; and being recognised, we can conceive no better method of repairing the loss than by the publication and wide distribution of information such as we find in the series before us.

THE INSTITUTION OF MINING ENGINEERS

THE annual meeting of the Institution of Mining Engineers, held at Sfeffield on September 4, 5, and 6 , was $7^{\text {ttended by }}$ large number of members. Cordial addyesses of wy come were delivered by Mr. J. R. R. I son, int of the Midland Institute of Mining En in eers by the Lord Mayor of Sheffield, and by Mr. A. J. Alobson, speaking on behalf of the Chamber of Commerce and of Sheffield University, who kindly lent the Firth Hall for the occasion. Mr. C. E. Rhodes was elected president for the ensuing year, and the report of the council, read by the secretary, Mr. M. Walton Brown, recorded a year of satisfactory progress. The institution is a federation of seven local mining societies, and its membership has grown from 1239 since the foundation in 1889 to 3100 at the present time. During the past year sixty-eight papers of a varied nature were published in the Transactions. Mention was made of the efforts being made, in conjunction with the British Science Guild, to secure a reduction of postage on the publications of scientific societies, and of the reports submitted by Mr. J. A. Longden, representative of the institution at the British Association, and by Mr. Bennett H. Brough, representative of the institution at the testing congress in Brussels. It was also noted that Mr. Arthur Sopwith, senior past-president, represented the institution on the governing body of the Imperial College of Science and Technology.

Three papers were read and discussed. The first, by Mr. J. W. Fryar and Mr. Robert Clive, described the 
sinking of two shafts through roo feet of quicksand at Bentley Colliery. In the second Mr. H. T. 'Foster dealt with the subject of roof weights in mines, his views being deduced from observations in long-wall workings. Lastly, Mr. H. St. John Durnford described a deep boring put down on the Earl of Londesborough's estate, near Selby, in the hope of finding a workable seam. Although some Io6o feet of Middle Coal-measures strata were proved, boring was continued to a depth of 237 I feet without any good seam being encountered. It is probable that the bore-hole passed down through the limb of a fold where the seams had either thinned or pinched out altogether. In the afternoon of September 4 the members visited the Tinsley steel, iron, and rope works, and the East Hecla works of Hadfield's Steel Foundry Company, Ltd. At the dinner in the evening Sir William Clegg, in proposing the toast of the Institution of Mining Engineers, incidentally referred to the new Imperial College of Science and Technology, and stated that a deputation from Sheffield had waited upon Lord Crewe to urge that mining and metallurgy should be taught at Sheffield in the centre of mining and metallurgy, rather than centralised in London.

On September 5 the members visited the Clyde Steel Milling Works, Bentley Colliery, and Silverwood Colliery ; and the meeting concluded with a drive, on September 6, to the Derwent Valley waterworks.

\section{METEOROLOGICAL OBSERVATIONS.}

SEVERAL reports of meteorological observatories have recently been received, and four of them are of noteworthy interest. The report of the observatory department of the National Physical Laboratory for 1906 shows that the value of t/e/ instryenty certificates is very generally oprectated number of instruthe total bo 20,567 . There was a marked increase in the number $f$ marine chronometers submitted to trial, more than 20 per cent. of which failed to pass the test. In the magnetic department the curves were free from any large disturbances. The largest movements of the seismographs occurred on January 31 , April I8, and August 17, the dates of the Colombian, Californian, and Chilian earthquakes. The meteorological observations show that shade temperatures exceeding $80^{\circ}$ were recorded in each of the four months June-September, the extreme reading being $9 \mathrm{I}^{\circ} \cdot 8$ on September 1. Rainfall amounted to 23.68 inches (nearly half an inch below the average for Greenwich for the sixty-five years 1841-1905); the greatest daily fall was 2.36 inches on June 28 , and was within half an inch of the total amount for that month.

The report of the director of the Bombay Government Observatory for 1906 gives room for little comment, excepting that the operations, which deal especially with terrestrial magnetism, meteorology, and seismology, were carried out with the usual care and punctuality. The maximum temperature was $94^{\circ}$ on October 23, being only about $2^{\circ}$ higher than the extreme reading recorded at the Kew Observatory. Owing to concussion from exceptionally heavy gun-firing at Colába the dry-bulb thermograph was broken in June. The yearly rainfall amounted only to $56 \cdot 3$ inches, being nearly ig inches below the normal of twenty-four years (1873-96). Milne's seismograph registered fifty-nine earthquakes during the year; of these three were very great disturbances, viz. January 31 , August 17 , and October 24; the two first mentioned correspond to the dates of the Colombian and Chilian earthquakes.

The fiftieth year-book of the Austrian Central Meteorological Office, for 1905, contains hourly and daily observations at some selected stations, as before; the results at other stations are arranged either according to the international scheme or in tables showing monthly and yearly means and extremes. The stations number 4I2, of which fifty are more than rooo metres $(3280$ feet) above sea level; this number in no way represents the whole of the valuable Austrian meteorological work, as there are several independent organisations dealing more particularly with rainfall and temperature, the principal of which is the hydrographic department, with more than rooo stations, for eighty of which the observations are printed in extenso. The. Hungarian and other meteorological services also issue separate year-books. The Vienna Meteorological Office deals specially with earthquake phenomena and with the collection and discussion of thunderstorm observations, the results of which are printed separately; it also publishes a daily weather report, and takes an active part in the investigation of the uppes air by means of balloons.

In the annual report of the meteorological department of the Transvaal for the year ended June 30, 1906, the results of observations are well arranged in appendices, as before; the hourly readings at Johannesburg are not now printed in extenso, but MS. copies are available, on loan, for special inquiries. The stations have increased in number to 376 , most of which record rainfall only; all the observers are volunteers, or are attached to other departments. The rainfall was considerably below the average in all parts except in the S.W., where the defect was only slight; no snowfall was reported during the year. A forecast of the weather for the ensuing twentyfour hours is now exhibited at every postal telegraph station in the Transvaal. The director (Mr, R. T. A Innes) seems dissatisfied with the Campbell-Stokes sunshine recorder, which only shows the time during which the sun is sufficiently powerful to burn the cards; in future reports both the duration and burning times will be given.

\section{RUSSIAN SCIENTIFIC WORKS.}

THE Imperial University of Kazan, with/j s society of naturalists, is noted for excellent woth in many departments, and we are greatly igpresed with the magnitude of Mr. M. Ruszky's volym "The Ants of Russia,

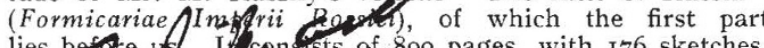
lies 18 Insts of 800 pages, with 176 sketches, compriang fan froduction, bibliography, systematic examinftion of Rlssian ants, list of collectors to whom the author is indebted, and indexes. Mr. Ruszky began the study of Russian myrmecological fauna in 1892 , when he undertook a zoological excursion in the Kazan and Simbirsk governments on behalf of the Society of Naturalists. He was induced to take up this investigation partly because Russian ants had been very little studied, and partly for the collection of materials for the solution of biological and zoo-geographical questions. This work is to be understood as a preliminary array of results, being an attempt at a description of Russian ants in systematic geographical and biological respects. The author anticipates criticism for omission of questions of internal morphology and embryology, and observes that such exhaustive treatment of the Formicidæ by a single investisator would occupy, not one, but many decades. In the important bibliography of writings on ants, occupying with addenda about seventy pages, very few works are devoted to Russia, chief among the number being twelve by the author. Mr. Ruszky estimates the approximate total of species and subspecies known at the time of writing at 3500 , and groups Russian ants under the $s$ ibfamilies Camponotinæ, Dolichoderinæ, Myrmecinæ, and F'onerinæ. Representatives of Dorylinæ, principally found in the tropics, have not been seen in Russia, though one species (Dorylus juvenculus) is European, being found in southern Italy, Sicily, \&c. After some useful preliminary notes and tables of species of Russian ants, the author proceeds to detailed descriptions of smaller groups. In all, $25^{8}$ forms are described ( 155 species and races, 103 varieties), of which sixty are new and treated for the first time (subfamilies, Camponotinæ, I09; Dolichoderinæ, 7; Myrmecinæ, 138; and Ponerina, 4). The regions richest in myrmecological fauna are the Caucasus, with 130 forms; Russian Central Asia, about 112: European Russia, 92 Siberia, 7I; Crimea, 43; and Finland, 32. All these figures are approximate, and it is probable that since this work appeared more results have been recorded. This first part gives geographical distribution, locality, and biological information, and in the second Mr. Ruszky proposes to deal with this fauna from the bio-geographical paint of view.

Vol. xxxiv. of the Transactions of the St. Petersburg

NO. 1976, VOL. 757 